DOI:

Cite this as:

Santoso, Devina Kurniawan, Handayani, Penny. Psychological Adjustment Effectivity In Elder Siblings Of Children With Down Syndrome. Indonesian Journal of Disability Studies (IJDS).2018: Vol. 5(2): PP 231-240.

\title{
PSYCHOLOGICAL ADJUSTMENT EFFECTIVITY IN ELDER SIBLINGS OF CHILDREN WITH DOWN SYNDROME
}

\author{
${ }^{1 *}$ Devina Kurniawan Santoso, ${ }^{2}$ Penny Handayani \\ ${ }^{1,2}$ Fakultas Psikologi, Universitas Katolik Indonesia Atma Jaya Jakarta
}

\begin{abstract}
Elder siblings play an important role in the family such as being a replacement caregiver for the children with Down syndrome. Therefore, they need an effective psychological adjustment to fulfill the responsibility. The purpose of this study is to describe the effectiveness of psychological adjustment in elder siblings of a Down syndrome children. This research was done using narrative qualitative method by interviewing and observing four elder sibling of children with Down syndrome. Each participant has different combinations of age-spacing with the Down syndrome children and number of siblings. The result shows some variety of effectiveness of psychological adjustment within each participants. The variety was caused by some individual factors, such as parents involvement and siblings' relationship quality.
\end{abstract}

Keywords: psychological adjustment, siblings, Down syndrome

\section{Latar Belakang}

Berdasarkan data yang diterbitkan oleh Riskesdas pada tahun 2003, sebanyak 0,53\% anak dilahirkan dengan kekurangan atau memiliki gangguan perkembangan tertentu, baik secara fisik maupun psikis ${ }^{i}$. Hal ini dapat terus mempengaruhi kualitas tumbuh kembangnya di kemudian hari. Salah satu gangguan yang menyebabkan adanya ketidaksesuaian tahap perkembangan jika dibandingkan dengan anak lain seusianya adalah sindroma Down. Secara fisik, anak dengan sindroma Down memiliki postur tubuh dan bentuk wajah yang cukup khas. Anak dengan sindroma Down juga memiliki potensi besar mengalami intellectual disability, namun dengan tingkat keparahan yang berbeda-beda. Hal ini sangat mempengaruhi kemampuan anak dalam menjalani kehidupannya sehari-hari. Bahkan, anak pun dapat mengalami kesulitan untuk mengurus dirinya sendiri. Dengan demikian, anak dengan Sindroma Down perlu mendapatkan pengawasan dan bantuan sepanjang hidupnya.

Perkembangan fisik dan mental yang terhambat pada anak dengan sindroma Down menyebabkan anak yang bersangkutan, serta

* Corresponding author: Devina Kurniawan Santoso

devina.2014070087@student.atmajaya.ac.id

Published online at http://IJDS.ub.ac.id/

Copyright (C) 2018 PSLD UB Publishing. All Rights Reserved keluarganya sering kali menjadi pusat perhatian ketika berada di tempat publik. Hal ini dapat menjadi salah satu sumber stres karena menyebabkan keluarga merasa tidak nyaman ataupun malu, sehingga keluarga sulit untuk menerima kehadirannya. Stres dan beban yang dirasakan orang tua juga semakin didukung oleh adanya penolakan dari lingkungan sekitar, termasuk keluarganya sendiri. Penolakan tersebut sering kali terjadi karena adanya kekurangan pada kemampuan intelektual anak dengan sindroma Down. Selain keterbelakangan perkembangan mental, perbedaan ciri fisik yang cukup menonjol pada anak sindroma Down juga sering kali membuatnya mendapatkan stigmatisasi dari masyarakat. Stigmatisasi merupakan bentuk reaksi atau respon sosial yang negatif pada seseorang yang diberikan stigma atau suatu penilaian negatif karena adanya karakteristik tertentu ${ }^{i i}$.

Kondisi ini membuat masyarakat sering kali menganggap rendah, bahkan melakukan diskriminasi pada anak dengan sindroma Down ataupun kebutuhan khusus lainnya. Hal ini juga turut menjadi sumber stres bagi orang tua dengan anak berkebutuhan khusus dan sulit untuk menerimanya. Cicirelli mengatakan bahwa psychological distress yang dirasakan oleh orang tua dengan anak berkebutuhan 
khusus, dapat memberikan dampak tertentu bagi anak lainnya. Psychological distress merupakan kondisi psikologis yang membuat individu merasa tidak nyaman dan dapat mengganggu aktivitas sehari-hari. Keadaan ini digambarkan dengan adanya kecemasan, kesedihan, atau gejala gangguan psikologis lainnya. Hal ini dapat mempengaruhi reaksi yang akan diberikan oleh anak pada saudara kandung yang terdiagnosa sindroma Down, seperti munculnya penolakan.

Kehadiran saudara kandung dapat memberikan beberapa fungsi yang tidak dapat digantikan oleh orang tua, seperti selalu siap dan sedia untuk menemani saudaranya dalam berbagai hal. Dalam keluarga, hubungan saudara kandung merupakan hubungan yang paling lama, sehingga saudara kandung juga memiliki perpanjangan fungsi untuk menggantikan peran orang tua bagi adikadiknya. Adanya hubungan yang permanen antara saudara kandung menyebabkan setiap individunya memiliki pengaruh yang cukup besar satu sama lain. Kelekatan dan hubungan yang dibangun antar saudara kandung diyakini memiliki banyak pengaruh positif bagi anak. Hubungan antar saudara kandung yang terjalin dengan baik dapat membantu anak untuk memenuhi kebutuhan sosialnya dan kebutuhan dalam aspek lainnya. Furman dan Buhrmester ${ }^{\text {iii }}$ menyebutnya sebagai hubungan saudara kandung yang menunjukkan kehangatan (warmth) atau kedekatan (closeness). Tipe hubungan ini ditandai dengan adanya perilaku prososial, kasih sayang, serta pengasuhan (nurturance atau caretaking). Menurut Cicirelli ${ }^{5}$ tipe hubungan ini dapat membantu seseorang menerima kehadiran saudaranya yang merupakan anak berkebutuhan khusus.

Di samping hubungan saudara kandung yang positif dan saling mendukung, hubungan saudara kandung dapat dipenuhi oleh konflik. Tipe hubungan ini digambarkan dengan banyaknya pertengkaran yang terjadi. Selain itu, tipe hubungan saudara kandung lainnya adalah hubungan yang menunjukkan persaingan atau kompetitif. Dalam tipe hubungan ini, perhatian dan perilaku yang ditunjukkan oleh orang lain menjadi hal yang penting, karena dapat menimbulkan prasangka ada anak lebih diutamakan daripada anak lainnya. Hubungan saudara kandung yang konfliktual dan kompetitif rentan terjadi pada seorang anak yang baru saja memiliki adik, terutama bila adik memiliki kebutuhan khusus. Keadaan ini dapat menyebabkan orang tua semakin banyak mencurahkan perhatiannya pada anak yang bersangkutan dan membuat sang kakak merasa tidak mendapatkan perhatian. Hal ini juga dapat menyebabkan kurang efektifnya penyesuaian psikologis pada kakak yang memiliki adik berkebutuhan khusus, seperti sindroma Down.

Penyesuaian psikologis yang kurang baik dikatakan dapat menimbulkan rasa takut dan cemas untuk berinteraksi dengan adiknya yang memiliki kebutuhan khusus ataupun kepahitan dan kebencian terhadap adiknya. Mengingat adanya tanggung jawab sebagai seorang kakak, penyesuaian psikologis menjadi hal yang penting dalam hubungan saudara kandung. Guna mewujudkan hal ini, saudara kandung perlu memiliki kualitas hubungan yang baik di antara mereka. Oleh karena itu, penyesuaian psikologis merupakan salah satu hal yang diperlukan agar sebagai saudara kandung, kakak dan adik dapat saling mengerti dan memiliki hubungan yang baik. Powell dan Gallagher mengatakan bahwa penyesuaian psikologis yang kurang efektif dapat menimbulkan potensi masalah emosi dan perilaku pada sang kakak. Hal ini dapat berdampak pada pemilihan karir dan kondisi keluarganya di masa depan jika dibiarkan berlarut-larut. Kondisi ini terutama mulai tampak saat kakak telah memasuki usia dewasa awal.

Menurut Santrock, dewasa awal merupakan tahap perkembangan yang dialami individu saat ia berusia 18 hingga 25 tahun. Pada tahap ini, individu memiliki karakteristik adanya eksplorasi identitas, terutama pada ranah karir dan asmara. Oleh karena itu, sesuai dengan yang diungkapkan Powell dan Gallagher, pengalaman individu yang sebelumnya dapat berkontribusi pada pemilihan karir dan kondisi keluarganya mendatang. Selain itu, individu mulai bersifat independen dalam berbagai aspek kehidupannya. Individu sangat terbuka pada kesempatan untuk mencoba berbagai macam hal sebelum mengambil keputusan mengenai identitas dirinya tersebut. Akan tetapi, kesempatan ini dapat membawa individu pada perilaku berisiko tinggi apabila tidak memiliki penyesuaian psikologis yang baik terhadap keadaan dirinya. 


\section{Kajian Pustaka}

\subsection{Penyesuaian psikologis}

Penyesuaian psikologis berarti membiasakan diri atau belajar untuk hidup dalam suatu keadaan tertentu. Hal ini juga berarti bahwa individu dapat menerima setiap keterbatasan dan segala situasi yang berada di luar kontrolnya. Bersamaan dengan itu, individu diharapkan dapat secara aktif melakukan modifikasi atau mengusahakan perubahan pada situasi yang masih dapat diperbaiki. Harber dan Runyon juga mengatakan bahwa penyesuaian psikologis merupakan suatu proses yang akan terus berlangsung sepajang hidup. Hal ini disebabkan karena dalam hidupnya, setiap individu akan terus mengalami perubahan pada berbagai situasi yang ada. Oleh karena itu, efektivitas penyesuaian psikologis dapat dilihat melalui kemampuan individu untuk mengatasi setiap tekanan atau konflik yang muncul karena adanya perubahan tertentu. Definisi penyesuaian psikologis yang digunakan dalam penelitian ini adalah proses belajar atau membiasakan diri yang telah dilalui seseorang agar mampu hidup sebagai seorang kakak dengan adik sindroma Down.

\subsection{Karakteristik Penyesuaian Psikologis yang Efektif}

Menurut Harber dan Runyon, berikut ini merupakan karakteristik individu yang melakukan penyesuaian psikologis secara efektif, yaitu:

- Persepsi yang tepat mengenai realita

Persepsi yang tepat mengenai realita berkaitan dengan interpretasi individu mengenai suatu situasi. Individu dapat menetapkan suatu target realistis yang secara aktif diusahakan tercapai. Dalam proses pencapaian target tersebut dapat terjadi beberapa modifikasi target akhir ataupun proses pencapaiannya. Selain itu, persepsi yang tepat juga menunjukkan kemampuan individu untuk memahami konsekuensi dari setiap perbuatannya. Dengan demikian, kemampuan tersebut diharapkan dapat mengarahkan individu pada suatu keputusan yang tepat.

- Kemampuan untuk mengatasi stres dan kecemasan

Perubahan-perubahan yang terjadi dalam hidup dapat membawa dampak positif maupun negatif. Perubahan yang positif dapat mengarah pada kebahagiaan ataupun kesuksesan, namun perubahan yang negatif dapat mengarah pada konflik, kegagalan, dan masalah lainnya. Perubahan negatif dapat menyebabkan timbulnya stres dan kecemasan. Pada bagian ini, efektivitas penyesuaian psikologis individu dapat dilihat melalui kemampuannya menangani perubahan-perubahan dalam hidup yang dapat menimbulkan stres dan kecemasan.

- Citra diri (self-image) yang positif Individu yang memiliki penyesuaian psikologis yang baik, dapat ditandai dengan adanya citra diri yang positif. Akan tetapi, dalam menilai dirinya, individu tidak dapat hanya melihat pada kelebihan atau kemampuannya saja. Individu perlu mengetahui dan memahami seluruh kemampuan serta keterbatasannya. Akan tetapi, individu diharapkan untuk tidak larut dalam keterbatasannya, melainkan dapat mengusahakan perubahan pada keterbatasannya secara optimal.

- Kemampuan untuk menyatakan berbagai emosi secara wajar

Kemampuan mengontrol emosi adalah masalah yang cukup banyak ditemui oleh individu. Di satu sisi terdapat individu yang mengontrol emosinya secara berlebihan, sehingga kurang mampu menunjukkan ekspresi yang tepat atau sering disebut dengan blunted effect. Di sisi lainnya terdapat individu yang tidak mampu mengontrol emosinya sehingga emosi yang dirasakannya dapat diekspresikan secara meluap-luap. pada penyesuaian psikologis yang efektif, kemampuan kontrol emosi individu diharapkan berada di antara keduanya, sehingga dapat menunjukkan emosi yang tepat pada situasi tertentu.

- Hubungan interpersonal yang baik Individu yang memiliki penyesuaian psikologis efektif dapat menikmati hubungan atau relasinya dengan orang lain. Individu dapat menikmati dikagumi dan dihormati oleh orang lain. Begitu pula sebaliknya, individu juga dapat mengagumi dan menghormati orang lain. Selain itu, 
individu juga dapat memaklumi adanya konflik dan kekecewaan dalam sebuah relasi. Dalam hal ini, kakak yang memiliki penyesuaian psikologis efektif diharapkan dapat menikmati hubungannya dengan orang lain, terlepas dari kehadiran adiknya.

\subsection{Faktor Penyesuaian Psikologis Saudara Kandung}

Saudara kandung dapat memiliki proses penyesuaian diri yang berbeda-beda terhadap adik yang berkebutuhan khusus. Powell dan Gallagher menyatakan terdapat beberapa faktor yang menyebabkan perbedaan proses penyesuaian diri pada setiap individu, yaitu:

- Ukuran keluarga

Powell dan Gallagher serta Kaminsky dan Dewey mengatakan bahwa ukuran keluarga dapat berdampak pada penyesuaian diri seorang anak yang memiliki adik berkebutuhan khusus. Semakin banyak jumlah anak dalam suatu keluarga, dikatakan bahwa semakin besar pula kemungkinan anak dapat menyesuaikan diri dengan baik. McHale et al. dalam Kamisnsky dan Dewey mengatakan bahwa semakin besar keluarga, maka semakin kecil pula rasa malu dan beban yang dirasakan karena memiliki saudara dengan disabilitas. Memiliki saudara yang lebih banyak, maka akan semakin banyak pula dukungan sosial yang diperoleh individu untuk melakukan penyesuaian psikologis.

- Rentang Usia

Simeonsson et al. dalam Powell dan Gallagher menyebutkan bahwa semakin besar rentang usia antara anak dengan disabilitas dan saudara kandungnya, maka akan semakin besar pula kemungkinan saudara kandungnya dapat menyesuaikan diri dengan baik. Hal ini juga didukung oleh penelitian serupa yang dilakukan oleh Minnett et al. Hasil penelitiannya menunjukkan bahwa saudara kandung dengan rentang usia yang cukup besar atau lebih dari empat tahun, memiliki hubungan yang lebih positif. Hal ini disebabkan karena bila keduanya masih berada dalam usia sekolah, maka rasa persaingannya pun lebih tinggi, sehingga mengakibatkan kurang baiknya hubungan saudara kandung tersebut.

\subsection{Dinamika Keluarga dengan Anak Sindroma Down}

Seorang anak dengan sindroma Down terlahir dengan adanya keterbatasan dalam hal intelektual serta kondisi kesehatan, sehingga perlu didampingi dalam berbagai aktivitas yang dilakukannya. Keterbatasan tersebut tidak hanya berdampak pada hidupnya saja, melainkan juga pada kondisi keluarganya. Saat mengetahui anak lahir dengan sindroma Down, terdapat perasaan kecewa, terkejut, dan juga sedih dalam keluarga. Perasaan tersebut dapat berdampak pada respon yang diberikan oleh masing-masing anggota keluarga kepada anak dengan sindroma Down.

Menurut Bowes dan Hayes, anak dengan sindroma Down cenderung menerima pengasuhan yang berbeda dari kedua orangtuanya. Anak dengan sindroma Down lebih banyak mendapatkan pengasuhan dari ibunya. Berbeda dengan ayah, ia lebih banyak menghabiskan waktu bersama dengan anaknya yang berkembang sesuai anak lain pada umumnya. Ketika ayah sedang bersama anak dengan sindroma Down, interaksi yang dilakukan didominasi oleh kegiatan yang menyenangkan seperti bermain, bukan merawat.

Selain orangtua, anggota keluarga yang turut merasakan dampaknya adalah saudara kandung dari anak dengan sindroma Down. Mereka berjuang dengan perasaan marah, kecewa, cemburu, dan juga malu. Perasaan ini dapat turut mempengaruhi respon yang ditunjukkannya kepada saudara yang memiliki sindroma Down. Selain perasaan tersebut, respon saudara kandung juga dapat dipengaruhi oleh respon dan perasaan yang ditunjukkan oleh orangtuanya ${ }^{5}$. Apabila orangtua menunjukkan respon dan perasaan negatif atau pesimis pada anaknya yang memiliki sindroma Down, maka saudaranya pun dapat merasakan serta mengimitasi hal serupa. Orangtua juga dapat memberikan pemahaman pada anaknya dan turut membantu pengasuhan saudaranya yang memiliki sindroma Down karena saudara kandung juga memiliki peran penting. Peran dari saudara kandung tersebut terutama dapat dirasakan ketika orangtua sudah tak lagi dapat memberikan perhatian dan mengasuhnya.

\section{Metodologi}

Pendekatan yang digunakan dalam penelitian ini merupakan narrative research 
design. Penelitian naratif berusaha untuk memberikan gambaran suatu fenomena tertentu secara sistematis dan rinci. Penelitian ini akan berfokus untuk menggali pemahaman yang mendalam mengenai penyesuaian psikologis sang kakak, berikut dengan faktor-faktor yang dapat mempengaruhi penyesuaiannya. Pengambilan data dilakukan dengan qualitative interviews, yaitu wawancara yang tidak bersifat kaku mengikuti panduan, melainkan disesuaikan dengan situasi dan kondisi saat wawancara. Peneliti juga melakukan observasi pada interaksi yang dilakukan partisipan dan adiknya, baik secara langsung maupun melalui aktivitas yang ditunjukkan partisipan pada media sosialnya. Penelitian ini menggunakan teknik triangulasi sumber untuk menjamin kredibilitas data yang diperoleh, yaitu dengan melakukan konfirmasi data dari beberapa partisipan yang berbeda.

Partisipan penelitian terdiri dari empat orang yang telah dipilih dengan menggunakan homogenous sampling. Keempat partisipan penelitian memiliki variasi kriteria yang berbeda-beda atas dasar pengkombinasian faktor yang dapat mempengaruhi penyesuaian psikologis saudara kandung, yaitu jumlah saudara dan rentang usia dengan adik yang terdiagnosa sindroma Down. Hal ini disebabkan karena jumlah saudara kandung yang lebih besar dan rentang usia lebih dari empat tahun dapat mengarahkan individu pada penyesuaian psikologis yang lebih baik. Berikut merupakan kriteria partisipan penelitian ini:

- Kakak langsung dan memiliki rentang usia sampai dengan empat tahun

- Kakak langsung dan memiliki rentang usia lebih dari empat tahun

- Memiliki saudara kandung lain dan memiliki rentang usia sampai dengan empat tahun

- Memiliki saudara kandung lain dan memiliki rentang usia lebih dari empat tahun

\section{Hasil Pembahasan}

\subsection{Gambaran Penyesuaian Psikologis}

Berdasarkan data yang diperoleh, setiap partisipan terlihat memiliki efektivitas penyesuaian psikologis yang berbeda pada beberapa karakteristik yang dikemukakan oleh Harber dan Runyon. Pertama, persepsi mengenai realita. Keempat partisipan dapat dikatakan memiliki persepsi yang tepat mengenai realita yang dihadapi, yaitu sebagai seorang kakak yang memiliki adik sindroma Down. Hal ini dapat dilihat melalui adanya harapan-harapan realistis yang dimiliki oleh para subjek, baik untuk dirinya sendiri maupun untuk adik. Para partisipan juga melakukan secara aktif beberapa usaha untuk membantunya mencapai harapan tersebut. Dalam proses pencapaian harapannya pun tidak jarang para partisipan melakukan modifikasi usaha atau target akhir yang ingin dicapainya. Hal ini dilakukan karena para partisipan juga mempertimbangkan kondisi dan kemampuan adik mereka. Keempat partisipan memiliki harapan yang tentunya berbeda-beda bagi adik mereka. Akan tetapi, dalam mencapai harapan tersebut, para partisipan memiliki satu hal yang sering kali menjadi pertimbangannya untuk melakukan modifikasi, yaitu suasana hati para adik. Ketika adik mereka dirasa tidak dapat memenuhi harapannya, maka para partisipan tidak akan memaksa namun berusaha mencari alternatif lain atau mencoba usaha yang sama di lain kesempatan.

Kedua, kemampuan untuk mengatasi stres dan kecemasan. Tiga dari empat partisipan dapat dikatakan mampu menghadapi tekanan dengan cara yang berbeda-beda. Ketiganya berusaha untuk menghadapi dan menyelesaikan sumber tekanan yang dirasakannya tersebut. Ada partisipan yang mengatasinya dengan cara menekan (surpress) persepsi dan kecemasannya, namun ada pula yang meminta bantuan pihak lain, seperti orang tua, untuk mengatasi situasi tersebut. Ketiga partisipan tersebut berusaha menghadapi dan mencari solusi untuk mengatasi situasi tersebut. Walaupun demikian, satu partisipan melakukan hal yang berbeda. Partisipan berikut tidak berusaha mengatasi kecemasan yang dimilikinya, melainkan berusaha untuk menghindari sumber kecemasan tersebut. Hal ini terjadi terutama saat membahas mengenai pasangan hidup. Partisipan memiliki kecemasan mengenai penerimaan calon pasangannya terhadap adik yang terdiagnosa sindroma Down. Akan tetapi, kecemasannya menyebabkan ia berusaha menghindari membicarakan topik tersebut. Dengan demikian, kecemasan yang dimilikinya belum teratasi, melainkan hanya diabaikan untuk sementara waktu.

Ketiga, citra diri positif. Tiga dari empat partisipan memiliki citra diri yang positif 
sebagai seorang kakak dari adik sindroma Down. Hal ini terlihat dari pandangan positif ketiganya pada diri masing-masing. Ketiga partisipan tidak memandang kehadiran adiknya menjadi kekurangan dari dirinya, walaupun mereka memiliki tanggung jawab untuk membantu merawat adik-adiknya. ketiga partisipan juga mampu untuk terbuka pada orang lain, seperti teman ataupun kekasih. Mereka pun tidak segan untuk mengajak temanteman dan kekasihnya ke rumah, bertemu, bahkan berinteraksi langsung dengan adiknya. Berbeda dengan ketiga partisipan tersebut, satu partisipan belum sepenuhnya menunjukkan citra diri positif. Partisipan berikut mampu terbuka dan menujukkan citra diri positif di hadapan teman-teman dan keluarganya. Akan tetapi, ia menganggap adiknya sebagai salah satu kekurangan dirinya saat membicarakan mengenai pasangan hidup. Hal ini menyebabkan ia tertutup pada pasangannya mengenai kondisi adik yang dimilikinya.

Ke empat, mampu mengekspresikan emosi secara wajar. Seluruh partisipan mampu mengenali dengan baik emosi-emosi yang dirasakannya. Akan tetapi, mereka cenderung memiliki cara yang berbeda-beda dalam mengekspresikan emosinya tersebut. Dua partisipan mampu megekspresikan emosi secara wajar dan konstruktif. Ketika merasakan emosi negatif, keduanya mampu mengekspresikan emosinya tersebut secara langsung pada orang yang bersangkutan, termasuk adiknya. Akan tetapi, saat emosi negatif yang dirasakannya mulai berlebihan, maka meminta bantuan orang lain atau menenangkan diri dahulu dapat menjadi alternatif solusi berikutnya. Hal ini cukup berbeda dengan dua partisipan lainnya. Dua partisipan lainnya cenderung mengungkapkan emosi secara berlebihan, baik dengan melibatkan fisik maupun menegur dengan kata-kata yang kurang sopan dan kurang menghargai.

Ke lima, hubungan interpersonal yang baik. Tiga dari empat partisipan mampu memiliki hubungan personal yang baik dengan orang lain. Ketiga partisipan mampu menikmati interaksi yang dilakukannya dengan orang lain, terlepas dari ada atau tidaknya adik mereka. Ketiganya juga mampu menunjukkan sikap menghargai orang lain saat berinteraksi, walaupun situasi tersebut membuatnya merasa tidak nyaman. Bahkan ketiganya berusaha untuk memahami persepsinya bila berada pada posisi orang yang bersangkutan. Satu partisipan lainnya juga mampu menikmati hubungannya dengan orang lain, terlepas dari kehadiran adiknya pada situasi tersebut. Akan tetapi, ia kurang mampu menghargai orang lain, terutama saat merasa mendapat tekanan atau tidak nyaman. Hal ini dapat dilakukannya pada siapapun, baik orang yang dikenalnya maupun tidak.

\subsection{Faktor Penyesuaian Psikologis Saudara Kandung}

Selain karakteristik penyesuaian psikologis di atas, terdapat beberapa faktor yang turut mempengaruhi para partisipan dalam menjalani kehidupannya sebagai kakak dari adik dengan sindroma Down, yaitu:

1. Keterlibatan orang tua

Berdasarkan data yang diperoleh dari keempat partisipan, terlihat bahwa kontribusi orang tua turut mempengaruhi penyesuaian psikologis para partisipan. Sejak para partisipan masih kanak-kanak, penjelasan orang tua mengenai kondisi adiknya tampak diperlukan oleh para partisipan. Partisipan yang mendapatkan penjelasan dari orang tua mengenai kondisi adiknya, menunjukkan sikap lebih mampu memahami segala kelebihan dan kekurangan adiknya.

Selain memberikan penjelasan mengenai kondisi adik, orang tua juga dapat berkontribusi dengan memberikan himbauan dan dukungan bagi para partisipan untuk menunjukkan kasih sayang pada adiknya. Para partisipan yang mampu menunjukkan kasih sayang pada adiknya, menerima dorongan dan nasihat-nasihat dari orang tuanya untuk bersikap baik pada adiknya. Orang tua juga dapat secara langsung menekankan tanggung jawab para kakak terhadap adiknya dan melibatkan mereka dalam aktivitas adiknya. Melalui data yang diperoleh, hal ini turut berkontribusi menambah pemahaman dan toleransi para partisipan pada adiknya yang terdiagnosa sindroma Down. Selain itu, melibatkan para partisipan dalam pengasuhan adik juga dapat memupuk kasih sayang dan hubungan baik di antara keduanya.

2. Hubungan dengan saudara kandung lain, selain yang terdiagnosa sindroma Down

Berdasarkan pengalaman partisipan yang memiliki saudara kandung lain, keduanya menunjukkan bahwa hubungan 
yang terjalin di antara mereka dapat mempengaruhi penyesuaian psikologis. Partisipan yang memiliki hubungan baik dengan saudaranya menunjukkan karakteristik penyesuaian psikologis yang lebih efektif. Kehadiran saudaranya dapat membantu ia membagi tanggung jawab sebagai seorang kakak. Keduanya juga dapat bekerjasama dalam menangani sang adik.

Berbeda dengan partisipan ke dua. Partisipan berikut memiliki hubungan yang seadanya dengan saudara kandung lainnya. Hal ini membuat ia merasa tanggung jawab tersebut adalah miliknya, dan tidak dapat mengandalkan bantuan dari saudara lainnya. Selain itu, pengalaman berkeluarga milik saudaranya juga dijadikannya cerminan keluarga miliknya di masa mendatang. Hal ini menyebabkan semakin meningkatnya kecemasan yang dimiliki partisipan mengenai penerimaan pasangan hidup terhadap kondisi adiknya.

\section{Kesimpulan}

Penelitian ini memiliki tujuan untuk mengetahui gambaran penyesuaian psikologis kakak dengan adik sindroma Down, serta faktor yang mempengaruhinya. Berdasarkan analisis dan perbandingan yang telah dilakukan antar subjek, maka dapat disimpulkan bahwa setiap subjek menunjukkan efektivitas penyesuaian psikologis yang berbeda-beda. Penyesuaian psikologis para partisipan pun mulai tampak pada saat yang berbeda-beda pula.

Perbedaan penyesuaian psikologis ini dapat terjadi karena setiap partisipan memiliki beberapa karakteristik latar belakang yang berbeda. Pertama, perbedaan keterlibatan orang tua menunjukkan adanya perbedaan penyesuaian psikologis partisipan sebagai kakak dengan adik sindroma Down. Partisipan yang menerima intervensi dari orang tua menunjukkan penyesuaian yang lebih efektif sejak kanak-kanak, begitu pula sebaliknya. Kedua, hubungan dengan saudara kandung selain yang terdiagnosa memiliki sindroma Down. Partisipan yang memiliki hubungan yang dekat dengan saudaranya menunjukkan penyesuaian diri yang lebih efektif pula. Hubungan yang baik mendukung partisipan untuk saling bantu menjalankan tanggung jawabnya sebagai kakak.

\section{Diskusi dan Saran}

\subsection{Diskusi}

Perbedaan latar belakang setiap partisipan juga mengarahkan pada penyesuaian psikologis yang berbeda-beda. Partisipan yang tidak memiliki saudara kandung lain, menunjukkan adanya sikap tidak nyaman saat menyadari perbedaan kondisi adiknya pertama kali. Kehadiran adiknya juga menyebabkan partisipan merasa iri pada perhatian yang diberikan oleh orang tua pada adiknya. Hal ini terjadi karena anak merasa kehadiran adik menyebabkan perhatian orang tua terbagi, terutama dengan adanya kebutuhan khusus tersebut $^{11}$. Berbeda dengan partisipan yang memiliki saudara kandung lain, mereka telah terbiasa dengan situasi tersebut bahwa bukan hanya dirinya lah yang mendapatkan perhatian dari orang tuanya. Dengan demikian, saat adiknya dilahirkan, anak cenderung memiliki toleransi yang lebih tinggi dan terhindar dari rasa iri hati.

Penyesuaian para partisipan pada adik yang terdiagnosa sindroma Down mulai terlihat pada saat yang berbeda-beda. Ada partisipan yang sejak awal mampu memahami kondisi adiknya, ada juga yang baru mulai memahaminya saat berada di usia sekolah dasar. Partisipan yang sejak awal menunjukkan toleransi terhadap kondisi adiknya mendapatkan informasi dan himbauan dari orang tuanya sedini mungkin. Sedangkan, partisipan yang pada awalnya tidak memahami kondisi adik, menyatakan tidak menerima informasi atau himbauan dari orang tuanya. Mangunsong ${ }^{7}$ menyatakan bahwa informasi yang diberikan oleh orang tua merupakan salah satu kunci penyesuaian bagi saudara kandung lainnya. Peran orang tua sebagai mediasi diperlukan agar anak dapat memiliki pemahaman yang tepat mengenai kondisi adiknya. Selain itu, adanya mediasi dan dorongan dari orang tua dapat membawa hubungan saudara kandung tersebut ke arah yang lebih positif.

Selain memberikan informasi dan menjadi mediasi dalam hubungan anak-anaknya, orang tua juga memiliki pengaruh lain bagi penyesuaian anak-anaknya. Sikap yang ditunjukkan oleh orang tua bagi anaknya yang terdiagnosa sindroma Down, dapat mempengaruhi perilaku yang ditunjukkan seorang anak pada adiknya tersebut ${ }^{5}$. Apabila orang tua menunjukkan sikap positif pada anaknya yang terdiagnosa sindroma Down, 
maka anak lainnya pun dapat mengimitasi sikap positi orang tuanya saat berhadapan dengan adiknya tersebut, begitu pula sebaliknya.

Hal ini juga terlihat pada partisipan penelitian ini. Perilaku para partisipan terlihat serupa dengan perilaku yang ditunjukkan orang tuanya sehari-hari. Partisipan yang memiliki emosi meledak-ledak dan menggunakan fisik dalam mengungkapkannya, ternyata memiliki orang tua yang juga melakukan hal serupa. Saat merasa kesal pada anaknya, orang tua juga terbiasa menegur anaknya dengan cara memukul. Secara tidak langsung, hal ini dipelajari oleh sang anak dan diterapkan pula saat mengungkapkan emosi yang dirasakannya. Pengalaman ini menyebabkan partisipan merasa bahwa mengungkapkan emosi dengan cara memukul merupakan suatu hal yang wajar untuk dilakukan.

Powell dan Gallagher menyatakan bahwa ukuran keluarga memiliki pengaruh pada penyesuaian psikologis anak dengan adik berkebutuhan khusus. Semakin banyak jumlah anak dalam suatu keluarga, diasumsikan semakin besar pula kemungkinan seorang anak dapat menyesuaikan dirinya dengan baik. Adanya saudara kandung lain dapat membantu anak untuk membagi dan saling bantu dalam menjalankan tanggung jawabnya sebagai seorang kakak. Akan tetapi, pada penelitian ini ditemukan bahwa keadaan tersebut tidak dapat hanya dilandasi oleh jumlah saudara kandung yang dimiliki, melainkan turut dipengaruhi oleh kualitas hubungannya. Hubungan saudara kandung yang baik dapat meringankan beban dan tantangan yang dihadapi seorang anak. Akan tetapi, perubahan pada kualitas hubungan saudara kandung dapat menyebabkan perubahan pada kesejahteraan seorang anak pula. Hal serupa terjadi pada salah satu partisipan penelitian ini. Perubahan kualitas hubungan dan sikap saudara kandung secara tidak langsung menyebabkan timbulnya kecemasan pada salah satu aspek kehidupan partisipan. Perubahan ini menyebabkan partisipan merasa tidak dapat membagi tanggung jawab seorang kakak pada saudara lainnya. Partisipan menganggap bahwa adiknya merupakan tanggung jawabnya seorang diri, dan kembali meningkatkan kecemasan yang dirasakannya.

\subsection{Saran}

Penelitian ini memiliki beberapa keterbatasan. Pertama, pada penelitian ini, peneliti tidak dapat melakukan triangulasi pada salah satu partisipan. Oleh karena itu, peneliti kurang mendapatkan akses data yang lebih dalam mengenai pengalaman dari partisipan ini. Selain itu, data yang diberikan oleh partisipan didasari oleh ingatan yang dimilikinya tentang kejadian-kejadian tertentu. Hal ini juga menyebabkan adanya data yang kurang lengkap atau jelas mengenai pengalaman partisipan, terutama pada pengalaman awal mereka bertemu dengan adik. Data penelitian ini juga secara tidak sengaja bergantung pada empat partisipan dengan jenis kelamin perempuan, walaupun dianggap tidak mempengaruhi penyesuaian psikologis seseorang.

Berdasarkan keterbatasan penelitian ini, peneliti menemukan beberapa saran yang dapat dilakukan guna mendukung hasil penelitian selanjutnya, yaitu:

1. Peneliti melibatkan variasi jenis kelamin dalam menentukan kriteria partisipan. Hal ini ditujukan agar peneliti bisa memiliki gambaran yang lebih luas, dari sudut pandang laki-laki dan perempuan, mengenai pengalaman sebagai kakak dengan adik sindroma Down.

2. Peneliti disarankan memiliki waktu yang lebih banyak dalam proses pengambilan data penelitian. Waktu tersebut dapat digunakan oleh peneliti untuk membangun rapport yang lebih mendalam sehingga dapat meningkatkan keterbukaan setiap partisipan.

Berdasarkan kesimpulan hasil penelitian ini, terdapat beberapa hal yang dapat dijadikan acuan pihak tertentu agar dapat meningkatkan efektivitas penyesuaian psikologis kakak dengan adik sindroma Down:

1. Bagi orang tua

Orangtua diharapkan dapat melibatkan diri dalam hubungan anak-anaknya. Orang tua diharapkan dapat memberikan informasi mengenai kondisi anak yang terdiagnosa sindroma Down kepada para saudara kandungnya sedini mungkin, dengan memperhatikan pemilihan kata-kata yang digunakan. Orang tua juga dapat melibatkan anak dalam proses pengasuhan adiknya untuk meningkatkan kelekatan, sekaligus menyiapkan anak untuk menggantikan peran orang tua sebagai caregiver. Penting pula bagi orang tua untuk memberikan contoh sikap yang baik dan dorongan untuk mengasihi adiknya.

2. Bagi keluarga dan teman 
Pihak keluarga besar dan teman-teman diharapkan dapat memberikan dukungan kepada anak maupun orang tua yang memiliki anggota keluarga sindroma Down. Dukungan dapat diberikan dalam bentuk perhatian, baik pada anggota keluarga maupun anak yang mengalami sindroma Down.

\section{Daftar Pustaka}

Diono, A., Mujaddid, Prasetyo, F. A., \& Budijanto, D. (2014). Buletin Jendela Data dan Informasi

Kesehatan Situasi Penyanang Disabilitas. Jakarta: Kementerian Kesehatan RI.

Nolen-Hoeksema, S. (2014). Abnormal psychology (6th ed.). New York: McGraw-Hill Education.

Masykur, A. M., \& Rachmawati, S. N. (2016). Pengalaman ibu yang memiliki anak down syndrome. Jurnal Empati, 5, 822-823.

Bowes, J. M., \& Hayes, A. (Eds.). (1999). Children, Families, and Communities. South Melbourne:

Oxford University Press.

Cicirelli, V. G. (1995). Sibling relationships across the life span. New York: Plenum Press.

Borden, M. E. (2003). The baffled parent's guide to sibling rivalry. New York: McGrawHill.

Mangunsong, F. (2011). Psikologi dan pendidikan anak berkebutuhan khusus. Depok: LPSP3 UI.

Lamb, M. E., \& Sutton-Smith, B. (Eds.). (2014). Sibling Relationships: Their Nature and Significance Across the Lifespan. New York: Psychology Press.

Furman, W. \& Buhrmester, D. (1990). Perceptions of sibling relationships during middle childhood

and adolescence. Child Development, 61, 13871398. doi: 10.1111/j.1467-8624.1990.tb02869.x
Feist, J., Feist, G. J., \& Roberts, T.-A. (2013). Theories of personality. New York: McGraw Hill.

Macks, R. J., \& Reeve, R. E. (2007). The adjustment of non-disabled siblings of children with autism. Journal of Autism and Developmental Disorder, 37, 1060-1067. doi: 10.1007/s10803-006-0249-0

Powell, T. H., \& Gallagher, P. A. (2008). Brothers \& sisters: a special part of exceptional families (2nd ed.). Baltimore: Paul H. Brookes Publishing.

Santrock, J. W. (2013). Life-span development (14th ed.). New York: McGraw-Hill.

Arnett, J. J. (2000). Emerging adulthood: A theory of development from the late teens through the

twenties. American Psychologist, 55, 469-480. doi:10.1037//0003-066X.55.5.469

Harber, A. \& Runyon, R.P. (1984). Psychological of adjustment. Illinois: The Dorsey press.

Hallahan, D. P., \& Kauffman, J. M. (2006). Exceptional learners: introduction to special education (10th ed.). Boston: Person Education.

Kaminsky, L., \& Dewey, D. (2002). Psychosocial adjustment in siblings of children with autism. Journal of Child Psychology and Psychiatry, 43(2), 225-232. doi: 10.1111/14697610.00015

Minnett, A. M., Vandell, D. L., \& Santrock, J. W. (1983). The effects of sibling status on sibling interaction: influence of birth order, age spacing, sex of child, and sex of sibling. Child Development, 54(4), 1064-1072. doi: $10.2307 / 1129910$

Anggreni, N. M., \& Valentina, T. D. (2015). Penyesuaian psikologis orangtua dengan anak down

syndrome. Jurnal Psikologi Udayana, 186-187.

Retrievd from https://ojs.unud.ac.id/index.php/psikologi/articl elview/25198/16413 
DOI:

Hidajat, dkk. (2007). Panduan penyusunan dan penulisan skripsi. Jakarta: Fakultas Psikologi Unika Atma Jaya.

Yin, R. K. (2011). Qualitative research from start to finish. New York: The Guilford Press.

Patton, M. Q. (2002). Qualitative research and evaluation methods (3rd ed). California: Sage

Publication.

Richmond, M. K., Stocker, C. M., \& Rienks, S. L. (2005). Longitudinal associations between sibling relationship quality, parental differential treatment, and children's adjustment. Journal of Family Psychology, 19, 550-559. doi: 10.1037/0893-3200.19.4.550

Giallo, R., \& Gavidia-Payne, S. (2006). Child, parent and family factors as predictors of adjustment for siblings of children with a disability. Journal of Intellectual Disability Research, 50, 937-948. doi: 10.1111/j.13652788.2006.00928. 